\title{
Songbird Relationships to Shrub-Steppe Ecological Site Characteristics
}

\author{
Mary I. Williams, ${ }^{1}$ Ginger B. Paige, ${ }^{2}$ Thomas L. Thurow, ${ }^{3}$ Ann L. Hild, ${ }^{3}$ and Kenneth G. Gerow ${ }^{4}$ \\ Authors are ${ }^{1}$ Postdoctoral Research Associate, University of Wyoming, Laramie, WY 82071, USA; ${ }^{2}$ Associate Professor and ${ }^{3}$ Professors, Department \\ of Renewable Resources, University of Wyoming, Laramie, WY 82071, USA; and ${ }^{4}$ Professor, Department of Statistics, University of Wyoming, Laramie,
} WY 82071, USA.

\begin{abstract}
Rangeland managers are often faced with the complex challenge of managing sites for multiple uses and for the diverse interests of stakeholders. Standardized monitoring methods that can be used and understood by different agencies and stakeholders would aid management for long-term sustainability of rangelands. In the United States, federal land management agencies have recently based their assessments of rangeland health and integrity on state-and-transition models to consider management trajectories. Ecological sites provide a foundation for these efforts but have not been used to address wildlife habitat. Habitat preferences are documented for North American shrub-steppe songbirds but have yet to be related to ecological sites and site characteristics. We characterized ecological sites at Browns Park National Wildlife Refuge, Colorado, using established rangeland monitoring methods to test whether 1) songbird species density and diversity differ among adjacent shrub-steppe ecological sites and 2) quantifiable ecological site characteristics could be identified that account for significant variation in songbird density and diversity. Vegetation structure (represented as basal and canopy gaps, cover, height, and shrub density) differentiated the four ecological sites and was related to songbird density and diversity. Sage sparrows (Amphispiza belli) and vesper sparrows (Pooecetes gramineu) selected habitat based on horizontal characteristics of vegetation structure, such as basal and canopy gap and plant species cover. Brewer's sparrow (Spizella breweri), lark sparrow (Chondestes grammacus), and songbird diversity were more strongly related to vegetation structure of the plant communities than to plant composition. Our results support use of ecological sites as management units to characterize songbird habitat given that songbird density and diversity were related to site vegetation characteristics. By incorporating basal and canopy gap, height, plant cover, and shrub density monitoring methods into ecological site descriptions, managers would be provided with additional tools to assist in differentiating songbird habitat.
\end{abstract}

\section{Resumen}

El manejo de pastizales naturales frecuentemente presenta el desafío complejo de utilizar sitios para múltiples finalidades y atender a una diversidad de intereses de usuarios. Métodos de monitoreo estandarizados que puedan ser utilizados y comprendidos por diferentes agencias del gobierno y por usuarios interesados podrían ayudar a implementar prácticas de manejo que logren la sustentabilidad de largo plazo de los pastizales. En los Estados Unidos, las agencias federales que manejan tierras áridas, han comenzado a basar sus evaluaciones sobre el estado de salud y la integridad de los pastizales en modelos de estados-y-transiciones para considerar trayectorias de manejo. Los sitios ecológicos proveen el cimiento para dichos esfuerzos, pero no han sido utilizados en lo referente al hábitat de la fauna silvestre. Las preferencias de hábitat de aves cantoras de las estepas arbustivas de América del Norte han sido documentadas pero no han sido aún descriptas en el marco de los sitios ecológicos y sus características. Se caracterizaron los sitios ecológicos del Refugio Faunístico de Browns Park en Colorado utilizando métodos establecidos de monitoreo de pastizales naturales para determinar si 1) existen diferencias en la densidad y diversidad de especies de aves cantoras entre sitios de estepa arbustiva adyacentes y 2) existen diferencias cuantificables en las características de los sitios ecológicos que expliquen variaciones significativas en la densidad y diversidad de aves cantoras. La estructura de la vegetación (representada en término de aberturas basales y de canopeo, cobertura, altura, y densidad de arbustos) diferenció a los cuatro sitios ecológicos y estuvo asociada a la diversidad y densidad de aves cantoras. Dos especies de aves (Amphispiza belli y Pooecetes gramineu) seleccionaron hábitat sobre la base de las características horizontales de estructura de la vegetación tales como las aberturas basales y de canopeo y la cobertura de especies vegetales. Otras dos especies (Spizella breweri y Chondestes grammacus) y la diversidad de aves cantoras estuvieron más fuertemente asociadas a la estructura de la vegetación que a la composición de botánica de la misma. Nuestros resultados respaldan el uso de sitios ecológicos como unidades de manejo para caracterizar el hábitat de aves cantoras dado que la densidad y diversidad de las mismas estuvo asociada a las características de la vegetación del sitio. Al incorporar métodos de monitoreo de aberturas basales y de canopeo, altura de la vegetación, cobertura vegetal, y densidad de arbustos en la descripción de sitios ecológicos, quienes manejan los pastizales dispondrían de herramientas adicionales para ayudar a diferenciar hábitats de aves cantoras.

Key Words: gap intercept, songbird diversity, species composition, vegetation structure, wildlife habitat, Wyoming big sagebrush

Research was funded in part by the US Fish and Wildlife Service, US Geological Survey, and University of Wyoming

Correspondence: Mary Williams, Dept of Renewable Resources, 3354, University of Wyoming, Laramie, WY 82071, USA. Email: Mwillia9@uwyo.edu

Manuscript received 27 April 2010; manuscript accepted 6 December 2010. 


\section{INTRODUCTION}

Clear descriptions of ecological site characteristics are essential for inventory and management of rangeland natural resources. In response to the call for revised methods to inventory and monitor US public rangeland almost $20 \mathrm{yr}$ ago (National Research Council 1994), many US land management agencies (e.g., Natural Resources Conservation Service [NRCS], Bureau of Land Management [BLM], and Forest Service) have united their efforts to standardize assessments of rangeland health and integrity and to consider management trajectories (Pellant et al. 2005). Together, managers and researchers (e.g., US Geological Survey and Agricultural Research Service) have developed a systematic rangeland assessment that incorporates state-andtransition concepts of ecosystem function and is based on the identification and description of ecological sites (Pellant et al. 2005). Ecological sites are land areas with specific soil, topography, and climate that differ from each other in their ability to produce distinctive kinds and amounts of vegetation and in their response to management actions (Pellant et al. 2005). Ecological site descriptions are developed using site characteristics and observations of local experts. Once described, state-and-transition models are developed for each ecological site to model common and potential plant communities that may occur in response to ecosystem drivers (e.g., climate and management; Bestelmeyer et al. 2003). Within this standardized methodology, ecological sites are the basic land classification units for documenting soil, hydrological, and biological characteristics of current and potential condition (Peacock and Caudle 2005). Ecological site descriptions are being developed across the western United States and provide a communication and planning tool for land managers to assess site function. Wildlife habitat characteristics have not yet been explicitly incorporated into ecological site descriptions but would enhance this critical component of management of planning efforts.

In the North American shrub-steppe, changes in vegetation structure and function associated with exotic invasions, altered fire frequency, and mechanical interventions can be linked to the decline of songbird populations such as Brewer's sparrow (Spizella breweri) and sage sparrow (Amphispiza belli; Paige and Ritter 1999; Knick et al. 2003). Although habitat preference has been documented for some shrub-steppe songbirds, such preferences have not been recorded within an ecological site context. Individual songbird species have unique habitat affinities, and in a few cases, shrub-steppe songbirds can be closely tied to soil type (Dobler et al. 1996; Vander Haegen et al. 2000), suggesting that ecological sites, which are based on soils, are appropriate units for assessing songbird habitat conditions. Given the national effort to base monitoring standards on ecological sites, we conducted a study to link songbird habitat use to quantitative characteristics within and among ecological sites. Inclusion of wildlife habitat characteristics in ecological site descriptions would be a powerful step in facilitating monitoring and management.

We quantified characteristics on four shrub-steppe ecological sites in northwestern Colorado using established rangeland monitoring methods to test the hypotheses that 1) songbird species density and diversity differ among adjacent shrubsteppe ecological sites and 2) quantifiable ecological site characteristics can be identified that account for significant variation in songbird density and diversity.

\section{MATERIALS AND METHODS}

\section{Study Area}

The study was conducted on Browns Park National Wildlife Refuge, established in 1963 by the US Fish and Wildlife Service (USFWS), and adjacent public lands in Moffat County, Colorado (lat $40^{\circ} 48^{\prime} \mathrm{N}$, long $108^{\circ} 55^{\prime} \mathrm{E}$ ). The study area, approximately 8120 ha $(60 \%$ USFWS, 32\% BLM, and $8 \%$ Colorado State Land Board) has an average elevation of $1633 \mathrm{~m}$. Primary land uses of the study area are wildlife habitat, cattle production, and recreation. Average annual temperature is $7.4^{\circ} \mathrm{C}$ with average annual winter, spring, and summer temperatures of $-3.7^{\circ} \mathrm{C}, 7.2^{\circ} \mathrm{C}$, and $18.6^{\circ} \mathrm{C}$, respectively. Average annual precipitation is $216 \mathrm{~mm}$, most of which comes in the spring and fall. Elevation, soil, and vegetation data of the refuge and surrounding areas were integrated into a geographic information system to identify ecological sites. We obtained spatial soil data from SSURGO for Moffat County (Soil Survey Staff 2006) and vegetation data (30-m resolution) from the National Wildlife Refuge System. The study area is in the 180-230-mm precipitation zone of NRCS Major Land Resource Area 34A-Central Desertic Basins, Mountains and Plateaus, which extends into Wyoming and Utah. We concentrated our study on four shrub-steppe ecological sites: Loamy, Saline Lowland, Sandy, and SandySkeletal (Fig. 1). Soil pits from each ecological site were used to determine surface and subsurface textures, depth, and salinity.

\section{Site Characteristic Monitoring}

We measured site characteristics in 107100-m-radius plots (3.14 ha) stratified by ecological sites at $\geq 250 \mathrm{~m}$ apart. Each plot was sampled in 2006 and 2007 between May and August. Monitoring methods were adapted from Herrick et al. (2005a, $2005 \mathrm{~b}$ ) to capture the horizontal and vertical structure of site characteristics along three 50-m line transects arranged in a spoke design in each plot. Plant taxonomic names follow PLANTS database (US Department of Agriculture, NRCS 2010). Line-point intercept was used to measure type and amount of cover (dead and live vegetation by species, litter, biological crust, bare ground, and rock) and top canopy height intercepted at 50 points $(100-\mathrm{cm}$ spacing $)$ along each transect. Gap intercept measured spaces $(>20 \mathrm{~cm})$ between bases and canopies of two groups: all plants (annuals, perennials, and shrubs) and shrubs. Shrub gaps were distinguished from all plants to characterize horizontal shrub structure. To capture vertical shrub structure, height of intersecting shrub canopies was measured to the nearest centimeter. Basal and canopy gaps were calculated separately as the percentage of line covered in gaps $20-50,51-100,101-200$, and $>200 \mathrm{~cm}$ in length. Shrub density (shrubs $\cdot \mathrm{ha}^{-1}$ ) was measured in a $2 \times 50 \mathrm{~m}$ belt on each line transect in the plot. Shrubs within the belt transect were grouped by species into four height classes $(<10,10-50,51-$ 100 , and $>100 \mathrm{~cm}$ ). 


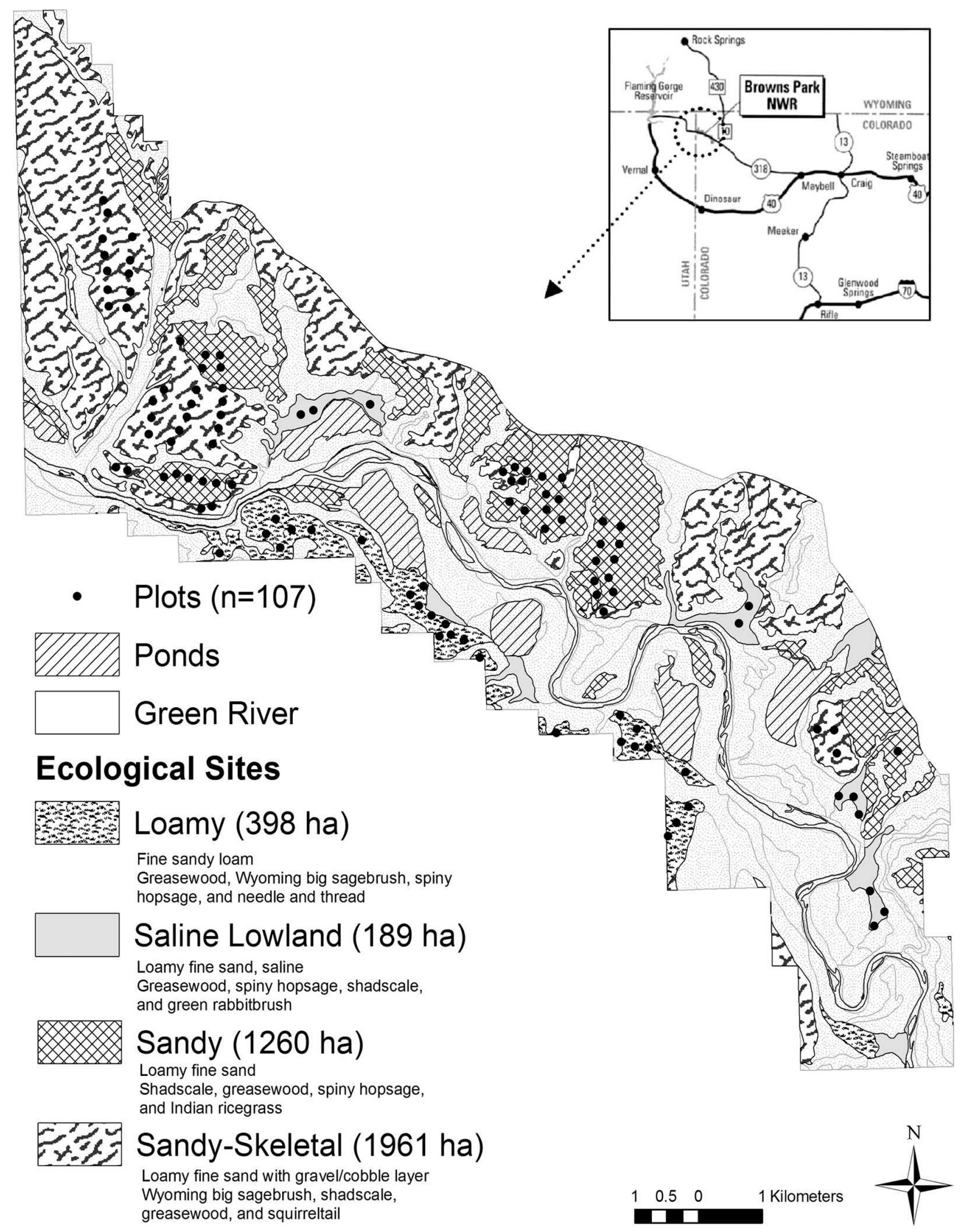

Figure 1. Monitoring plots (100-m radius), water features, and upland ecological sites at Browns Park National Wildlife Refuge, $97 \mathrm{~km}$ northwest of Maybell, Colorado. Loamy $(n=26)$, Saline Lowland $(n=11)$, Sandy $(n=31)$, and Sandy-Skeletal $(n=39)$ were delineated by soil texture characteristics and plant species composition. 


\section{Songbird Surveys}

Songbirds were surveyed in each of the 107 plots during the breeding season using fixed-radius (100-m) point-sampling methods (Bibby et al. 2000; Buckland et al. 2001). Survey dates were 6-11 and 26-31 May 2006 and 6-11 and 23-27 May 2007. One observer located at the plot center (same individual) surveyed songbirds between 0600 and 1000 hours on days with no precipitation and wind speeds less than $20 \mathrm{~km} \cdot \mathrm{h}^{-1}$. Following a 1-2-min settling period, locations of all singing male songbirds were identified within $100-\mathrm{m}$ radius from the center of each plot for $5 \mathrm{~min}$. Distances from the plot center were estimated using a laser range finder.

\section{Data Analysis}

We tested for differences in 60 site characteristics (response variables) among ecological sites (fixed factor) using general linear models (GLM) to account for unequal number of plots in each site. The number of plots within ecological sites was approximately proportional to the area of each site on the refuge. We tested for differences between observed years; results supported pooling of site characteristics data across year. Residuals were assessed for meeting the assumptions of GLM. When models detected differences (alpha $\leq 0.05$ ), ecological site means were separated using Fisher's Protected LSD test.

Songbird densities were derived using standard distance estimation methods for point transects (Buckland et al. 2001, 2009). We estimated density of the four most common species for which sufficient observations $(>60)$ allowed estimating a detection function: Brewer's sparrow, vesper sparrow (Pooecetes gramineu), lark sparrow (Chondestes grammacus), and sage sparrow. Species densities were estimated with program DISTANCE 5.0 Release 2 (Thomas et al. 2005). Although we assumed that the detection function for each species would not vary between years, we modeled detection functions for each year and evaluated their Akaike information criterion (AIC) values as recommended by Buckland et al. (2001). Results were in favor of pooling the data to obtain a detection function for each common bird species. Prior to modeling, at least $10 \%$ of the largest distances were truncated (Buckland et al. 2001). Key functions (half normal, hazard, and uniform) with hermite and cosine adjustments were used to model detection functions for each species. Model fit was evaluated with a $\chi^{2}$ goodness-of-fit test, and AIC with a second-order correction for small sample size (AICc) was used to select the most robust model (Buckland et al. 2001). A uniform key function with two cosine adjustment terms was modeled for Brewer's sparrow density. Vesper sparrow densities were modeled with uniform key functions with one cosine adjustment term. Lark sparrow and sage sparrow were modeled with half-normal, hermite polynomial functions with no adjustment terms. Songbird diversity (species $\cdot \mathrm{ha}^{-1}$ ) was calculated as the number of equally common species required to generate the observed heterogeneity of the sample (Hill's reciprocal index; Hill 1973; Krebs 1999). Density and diversity were used as response variables in GLM to determine differences by ecological site.

Regression models were built with best subset regression methods using songbird diversity and density as response variables and site characteristics as independent variables. From the set of 60 site characteristics, we selected a subset of potentially plausible predictors of songbird species density and diversity based on their typical habitat associations. Mallow's C-p (a measure of model fit), standard deviations, and adjusted $R^{2}$ were used to identify the best model with up to four site characteristics in best subset regression methods. Easily interpreted models with the least number of characteristics were selected and fit with residual analysis and variance inflation factor (VIF) values to assess multicollinearity (VIF $>5.0$ ). Where density of any songbird species or songbird diversity differed among ecological sites, the regression models were run using a GLM with the songbird metric as the response variable, site characteristics as covariates, and ecological site as a categorical fixed factor to determine if ecological site adds additional power beyond what the site characteristics provide.

\section{RESULTS}

\section{Site Characteristics}

Twenty-nine of the 60 measured site characteristics differed among ecological sites (Table 1). Although we anticipated that ecological sites would differ in site characteristics, we wanted to determine which characteristics (and associated methods) consistently discerned among ecological sites and how these characteristics related to songbirds. Wyoming big sagebrush (Artemisia tridentata ssp. wyomingensis [Beetle and Young] Welsh), shrub cover, plant and shrub height, small canopy gaps $(<100 \mathrm{~cm})$, and shrub density differed among three sites (Table 1). Vegetation structure represented by gap (canopy and basal) and height together illustrate differences among four ecological sites in our study (Fig. 2).

\section{Songbird Density and Diversity}

Twenty-nine songbird species and 1070 male songbirds were recorded over the 2 yr. We detected shrub-steppe- and grassland-associated species of concern (Paige and Ritter 1999; Colorado Division of Wildlife 2003; Boyle and Reeder 2005), including Brewer's sparrow, green-tailed towhee (Pipilo chlorurus), horned lark (Eremophila alpestris), lark sparrow, sage sparrow, sage thrasher (Oreoscoptes montanus), Say's phoebe (Sayornis saya), vesper sparrow, and western meadowlark (Sturnella neglecta). Songbird diversity ranged from 0.75 species $\cdot \mathrm{ha}^{-1}$ on Saline Lowland sites to 1.18 species $\cdot \mathrm{ha}^{-1}$ on Sandy-Skeletal sites (Fig. 3). Diversity $\left(F_{1,3}=6.73, P<0.001\right)$ was highest in Sandy-Skeletal, lowest in Saline Lowland, and medium in Loamy sites. Brewer's sparrow was common $(32 \%$ of observations and an average density of $\left.1.28 \mathrm{birds} \cdot \mathrm{ha}^{-1}\right)$, as was vesper sparrow $\left(18 \%\right.$ and 0.45 birds $\left.\cdot \mathrm{ha}^{-1}\right)$. Less common songbirds were lark sparrow $\left(8 \%\right.$ and 0.21 birds $\left.\cdot \mathrm{ha}^{-1}\right)$ and sage sparrow $\left(8 \%\right.$ and 0.18 birds $\left.\cdot \mathrm{ha}^{-1}\right)$. Of these species, only vesper sparrow densities did not differ among ecological sites (Fig. 3). Brewer's sparrow densities were higher in Saline Lowland and Loamy than in Sandy-Skeletal sites $\left(F_{1,3}=2.83\right.$, $P=0.040)$. The species was detected in $>50 \%$ of the plots across all ecological sites. Lark sparrow density $\left(F_{1,3}=2.78\right.$, $P=0.040)$ was highest in Loamy and Sandy and lowest in Saline Lowland sites. Sage sparrow density $\left(F_{1,3}=11.58\right.$, $P<0.001)$ was higher in Sandy-Skeletal sites than in Loamy and Sandy sites. They were not detected in Saline Lowland sites. 
Table 1. Characteristics ( \pm SE of the mean) of four shrub-steppe ecological sites (no. of plots) in northwestern Colorado, measured in 2006 and 2007. Across ecological sites, characteristic means or medians followed by the same letter are not different $(P \geq 0.050)$. Characteristics in bold differ in at least three sites. Plant canopy height measured by line-point intercept; shrub canopy height measured by gap intercept. Plant and shrub canopy gaps are calculated as the percent of line covered in each gap size category; values will not total to $100 \%$.

\begin{tabular}{|c|c|c|c|c|c|}
\hline Characteristic & $P$ & Loamy (26) & Saline Lowland (11) & Sandy (31) & Sandy-Skeletal (39) \\
\hline \multicolumn{6}{|l|}{ Cover (\%) } \\
\hline Needle and thread & $<0.001$ & $3.7(0.9) \mathrm{a}$ & $0.0(0) \mathrm{b}$ & $0.2(0.1) b$ & $1.0(0.5) b$ \\
\hline Squirreltail & $<0.001$ & $0.1(0.1) b$ & $0.0(0) b$ & $0.3(0.1) b$ & $1.1(0.2) \mathrm{a}$ \\
\hline All perennial grasses & 0.033 & $4.2(1.0) \mathrm{a}$ & $1.7(1.3) a b$ & $0.9(0.2) b$ & $3.0(0.9) \mathrm{a}$ \\
\hline Greasewood & $<0.001$ & $8.0(2.2) b$ & $39.1(3.7)$ a & $5.7(1.1) b$ & $4.3(1.0) b$ \\
\hline Green rabbitbrush & 0.002 & $0.1(0.1) b$ & $4.2(2.1) \mathrm{a}$ & $0.2(0.1) b$ & $1.6(0.6) b$ \\
\hline Shadscale & $<0.001$ & $1.1(0.3) b$ & $0.7(0.5) b$ & $5.2(0.7)$ a & $5.9(0.7)$ a \\
\hline Spiny hopsage & 0.001 & $3.8(0.6) \mathrm{a}$ & $1.0(1.0) b$ & $3.8(1.0) \mathrm{a}$ & $0.8(0.3) b$ \\
\hline Wyoming big sagebrush & $<0.001$ & $4.1(0.9) \mathrm{b}$ & $0.0(0) \mathrm{c}$ & $0.6(0.3) \mathrm{c}$ & $8.5(1.3)$ a \\
\hline All shrubs & $<0.001$ & $17.3(1.9) \mathrm{C}$ & $45.9(3.0)$ a & $16.0(0.9) \mathrm{c}$ & $22.4(1.3) \mathrm{b}$ \\
\hline All perennial forbs and grasses & 0.002 & $2.8(0.7) \mathrm{a}$ & $2.8(1.3) \mathrm{a}$ & $0.5(0.1) b$ & $1.4(0.3) a b$ \\
\hline Total canopy & $<0.001$ & $32.8(2.3) b$ & $56.2(4.0) \mathrm{a}$ & $33.9(1.3) b$ & $33.9(1.6) b$ \\
\hline Bare ground & $<0.001$ & $42.0(2.4) \mathrm{a}$ & $27.1(3.0) \mathrm{b}$ & $39.8(2.0) \mathrm{a}$ & $41.6(1.8) \mathrm{a}$ \\
\hline Litter & 0.012 & $42.5(2.8) b$ & $52.1(3.4) \mathrm{a}$ & $40.2(1.9) \mathrm{b}$ & $39.5(1.5) b$ \\
\hline \multicolumn{6}{|l|}{ Height (cm) } \\
\hline Plant canopy & 0.001 & $26.9(1.9) \mathrm{b}$ & $40.5(3.2) \mathrm{a}$ & $22.8(0.9) \mathrm{C}$ & $20.2(0.9) \mathrm{c}$ \\
\hline Shrub canopy & $<0.001$ & $39.4(2.4) \mathrm{b}$ & $63.2(4.1)$ a & $31.0(1.4) \mathrm{C}$ & $28.9(1.1) \mathrm{c}$ \\
\hline \multicolumn{6}{|l|}{ Basal and canopy gaps (\%) } \\
\hline Plant canopy $20-50 \mathrm{~cm}$ & 0.018 & $5.8(0.8) b$ & $5.1(0.4) b$ & $5.9(0.6) b$ & $7.8(0.5) \mathrm{a}$ \\
\hline Plant canopy $51-100 \mathrm{~cm}$ & 0.001 & $11.9(1.1)$ bc & $8.7(0.8) \mathrm{c}$ & $13.1(0.9) a b$ & $15.1(0.7)$ a \\
\hline Plant canopy $101-200 \mathrm{~cm}$ & $<0.001$ & $18.4(1.1) \mathrm{a}$ & $12.3(0.9) b$ & $20.0(0.9) \mathrm{a}$ & $19.9(0.9) \mathrm{a}$ \\
\hline Plant canopy $>200 \mathrm{~cm}$ & 0.001 & $26.1(3.1) \mathrm{a}$ & $12.1(2.5) \mathrm{b}$ & $23.0(2.6) \mathrm{a}$ & $15.4(1.2) b$ \\
\hline Shrub canopy $20-50 \mathrm{~cm}$ & $<0.001$ & $2.4(0.3) \mathrm{C}$ & $4.4(0.5)$ ab & $3.1(0.3)$ bc & $5.8(0.5) \mathrm{a}$ \\
\hline Shrub canopy 51-100 cm & $<0.001$ & $6.9(0.7) \mathrm{c}$ & $7.5(0.8) \mathrm{c}$ & $9.2(0.7) b$ & $12.3(0.8)$ a \\
\hline Shrub canopy $101-200 \mathrm{~cm}$ & $<0.001$ & 14.6 (1.1) b & $11.6(1.1) b$ & $19.1(1.0) \mathrm{a}$ & $19.6(1.0) \mathrm{a}$ \\
\hline Shrub canopy $>200 \mathrm{~cm}$ & $<0.001$ & $45.4(2.7) \mathrm{a}$ & $18.6(3.4) b$ & $39.3(2.0) \mathrm{a}$ & $24.2(1.7) b$ \\
\hline Plant canopy median (cm) & 0.001 & $98.1(8.1)$ a & $69.8(4.9) \mathrm{b}$ & $88.5(5.4) \mathrm{a}$ & $71.3(2.2) \mathrm{b}$ \\
\hline Shrub canopy median $(\mathrm{cm})$ & $<0.001$ & $142.1(10.1) \mathrm{a}$ & $82.1(7.9) \mathrm{b}$ & $121.3(4.8) \mathrm{a}$ & $92.9(9.6) \mathrm{b}$ \\
\hline Shrub basal median $(\mathrm{cm})$ & 0.003 & $502.0(42.0) \mathrm{a}$ & $385.6(35.3) b$ & $550.1(38.8) \mathrm{a}$ & 383.7 (31.6) b \\
\hline \multicolumn{6}{|c|}{ Shrub density by height $\left(\right.$ no. $\cdot$ ha $\left.^{-1}\right)$} \\
\hline $10-50 \mathrm{~cm}$ & $<0.001$ & $8149(1542)$ bc & 3988 (841) C & $10859(978) b$ & $19228(1856)$ a \\
\hline $51-100 \mathrm{~cm}$ & $<0.001$ & $3320(392) b$ & $5906(601) a$ & $2037(263) \mathrm{c}$ & 1941 (229) C \\
\hline$>101 \mathrm{~cm}$ & $<0.001$ & $182(58) b$ & 1433 (341) a & $11(5) b$ & $26(9) \mathrm{b}$ \\
\hline
\end{tabular}

\section{Songbirds and Site Characteristic Relationships}

Vegetation structure represented as basal and canopy gaps, species cover, height, and shrub density were related to songbird density and diversity (Table 2). Sage sparrow and vesper sparrow models included horizontal vegetation characteristics, such as basal and canopy gap and plant species cover. Sage sparrows were strongly associated with Wyoming big sagebrush and bottlebrush squirreltail (Elymus elymoides [Raf.] Swezey) communities with basal gaps $>200 \mathrm{~cm}$. Vesper sparrows were positively tied to open-canopy shadscale communities and negatively related to winterfat (Krascheninnikovia lanata [Pursh] A. Meense \& Smit). Brewer's sparrow, lark sparrow, and songbird diversity models were closely tied to both horizontal (basal and canopy gap, plant cover, and shrub density) and vertical (height and shrub density) site characteristics. Brewer's sparrow was abundant in open plant communities with scattered, tall shrubs $(40-100 \mathrm{~cm})$. Lark sparrows also favored open plant communities, particularly short shrub communities containing broom snakeweed. Short, dense herbaceous communities with scattered shrubs, including rabbitbrush, were positively related to a diversity of songbird species.

Regression models for Brewer's and lark sparrow densities and songbird diversity were not improved with ecological site as a factor $(P>0.050)$. Brewer's sparrows, however, favored tall, open-canopy greasewood; Wyoming big sagebrush; and spiny hopsage communities, which were common in Saline Lowland, Loamy, and Sandy sites (Table 1). Lark sparrow densities and songbird diversity were supported by site characteristics common to Loamy, Sandy, and Sandy-Skeletal 

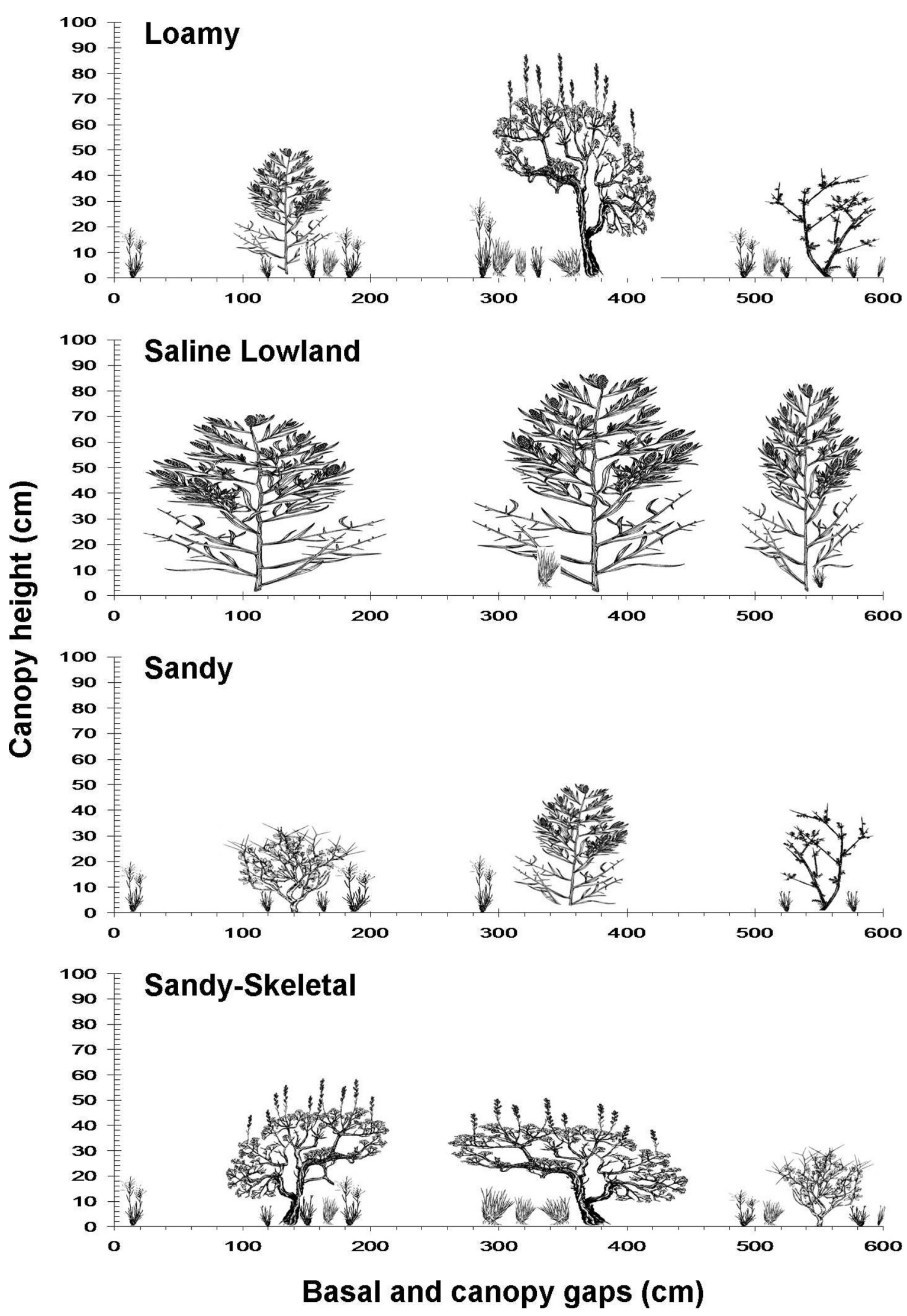

Figure 2. Generalized diagram of structural characteristics of four shrub-steppe ecological sites monitored with gap intercept and height measures. Axes represent average horizontal (basal and canopy gap on x-axis) and vertical characteristics (height on y-axis) of each site type. For example, Loamy sites support mixed height, open plant communities (basal gaps and shrub canopy gaps $>100 \mathrm{~cm}$ ) with dense understory vegetation (plant canopy gaps $<100 \mathrm{~cm}$ ). In comparison, Saline Lowland sites support tall $(>50 \mathrm{~cm}$ ), closed-canopy (canopy gaps $<100 \mathrm{~cm})$, and widely spaced plants (basal gaps $>100 \mathrm{~cm}$ ) with very little understory vegetation. Some plant illustrations were taken from Stubbendieck and Hatch (1997), used with permission. 
Table 2. Best subset regression models for songbird density (birds $\cdot$ ha $^{-1}$ ) and diversity (no. species $\cdot$ ha $\left.^{-1}\right)(n=107)$ surveyed in northwestern Colorado, 2006 and 2007. Median plant basal gap in meters. Plant canopy height (median) in decimeters measured with line-point intercept. Plant cover and gap in deciles. Variance inflation factor (VIF) values assess multicollinearity in models.

\begin{tabular}{|c|c|c|c|c|c|c|c|}
\hline Response & Model & Coefficient & $\mathrm{SE}^{1}$ & $P$ & VIF & $s$ & Adjusted $R^{2}$ \\
\hline \multirow[t]{4}{*}{ Brewer's sparrow } & Constant & -0.38 & 0.23 & 0.101 & & 0.8 & 0.352 \\
\hline & Plant basal gap (m) & 0.15 & 0.06 & 0.012 & 1.2 & & \\
\hline & Shrubs $\cdot \mathrm{m}^{-2}>100 \mathrm{~cm}$ tall & -7.2 & 1.85 & $<0.001$ & 2.0 & & \\
\hline & Plant canopy height (dm) & 0.64 & 0.11 & $<0.001$ & 2.3 & & \\
\hline \multirow[t]{4}{*}{ Vesper sparrow } & Constant & 0.22 & 0.13 & 0.088 & & 0.4 & 0.163 \\
\hline & Shadscale (\%) & 0.28 & 0.12 & 0.018 & 1.4 & & \\
\hline & Winterfat $(\%)$ & -0.41 & 0.16 & 0.014 & 1.0 & & \\
\hline & Shrub canopy gap $101-200 \mathrm{~cm}(\%)$ & 0.15 & 0.8 & 0.062 & 1.4 & & \\
\hline \multirow[t]{4}{*}{ Lark sparrow } & Constant & 0.12 & 0.06 & 0.069 & & 0.3 & 0.151 \\
\hline & Broom snakeweed (\%) & 2.2 & 0.61 & $<0.001$ & 1.0 & & \\
\hline & Shrub canopy gap > 200 cm (\%) & 0.03 & 0.02 & 0.094 & 1.1 & & \\
\hline & Shrubs $\cdot \mathrm{m}^{-2}>100 \mathrm{~cm}$ tall & -0.79 & 0.46 & 0.09 & 1.1 & & \\
\hline \multirow[t]{4}{*}{ Sage sparrow } & Constant & 0.14 & 0.04 & $<0.001$ & & 0.2 & 0.408 \\
\hline & Wyoming big sagebrush (\%) & 0.17 & 0.03 & $<0.001$ & 1.1 & & \\
\hline & Bottlebrush squirreltail (\%) & 0.79 & 0.19 & $<0.001$ & 1.1 & & \\
\hline & Plant basal gap 101-200 cm (\%) & -0.07 & 0.02 & 0.007 & 1.1 & & \\
\hline \multirow[t]{4}{*}{ Diversity } & Constant & 1.52 & 0.07 & $<0.001$ & & 0.3 & 0.273 \\
\hline & Plant canopy height (dm) & -0.17 & 0.03 & $<0.001$ & 1.2 & & \\
\hline & Shrub basal gap 101-200 cm (\%) & -0.27 & 0.07 & $<0.001$ & 1.0 & & \\
\hline & Green rabbitbrush (\%) & 0.25 & 0.08 & 0.003 & 1.2 & & \\
\hline
\end{tabular}

${ }^{1} \mathrm{SE}$ indicates standard error.

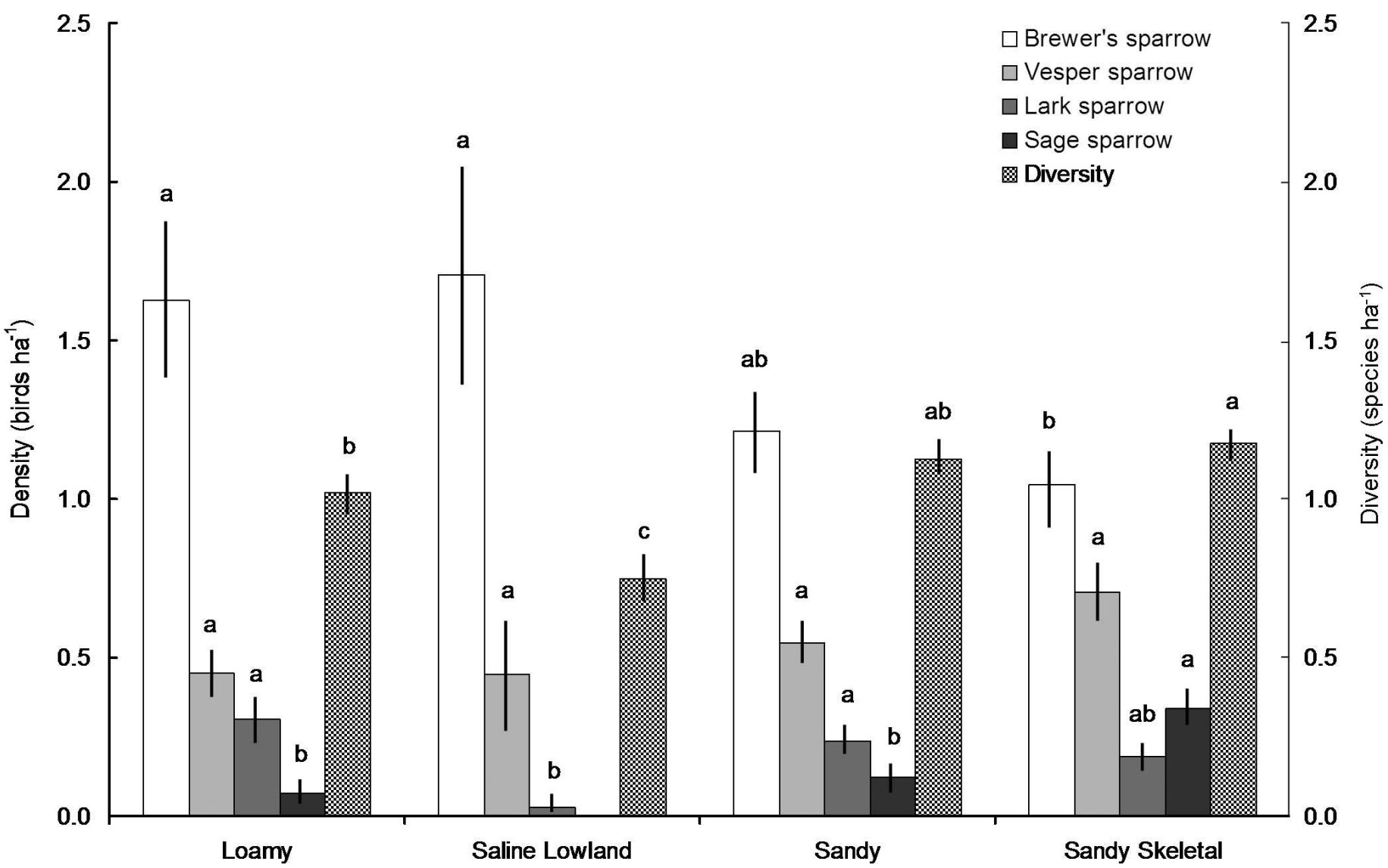

Figure 3. Songbird density and diversity $(n=107 ; \pm 1$ SE of the mean) in Loamy $(n=26)$, Saline Lowland $(n=11)$, Sandy $(n=31)$, and SandySkeletal $(n=39)$ ecological sites in northwestern Colorado. Across ecological sites, songbird diversity and density with the same letter are not different $(P \geq 0.05)$. Diversity is the reciprocal of Simpson's index (Hill 1973; Krebs 1999). 
sites (short, open-canopy plant communities). Sage sparrow densities increased with greater Wyoming big sagebrush cover, and ecological site improved the regression model for sage sparrow density (adjusted $R^{2}=0.460, F_{1,3}=4.31, P=0.007$ ).

\section{DISCUSSION}

Our results support the use of ecological sites as management units to characterize songbird habitat. Site characteristics that differ among ecological sites also differentiated habitat among the songbird species. Basal and canopy gaps and vegetation height were key structural characteristics that separated ecological sites and distinguished songbird habitat even where there were similarities in plant composition among ecological sites. Vegetation structure distinguished characteristics of both ecological sites and songbird habitat (Fig. 2; Table 2). For example, Loamy and Sandy-Skeletal sites had similar plant species composition, but their horizontal (basal and canopy gap) and vertical (height) characteristics differed substantially. Furthermore, we identified structural characteristics (horizontal, vertical, or both) important to songbirds even for songbird species that adhered to specific plant species associations. For example, sage sparrow favored sagebrush-dominated ecological sites but was associated with plant basal gap. Sage sparrows are thought to depend on large, continuous stands of tall sagebrush with little grass cover (Rich 1978; Knick and Rotenberry 1995; Paige and Ritter 1999) as opposed to mixed shrub or salt-desert communities (Wiens and Rotenberry 1981; Vander Haegen et al. 2000). Based on the literature, we expected higher sage sparrow densities in closed-canopy sagebrush communities. Instead, sage sparrows responded positively to closed-canopy and widely spaced mixed shrub communities. Vesper sparrows were common across the study area, but we found that horizontal structure (shrub canopy gap) was just as important to vesper sparrow as was plant composition. Vesper sparrows, considered a grassland songbird (Vander Haegen et al. 2000; Beason et al. 2005), are found in a variety of plant communities (Paige and Ritter 1999), but there are few reports of their association with vegetation structure. Though vesper sparrows are common in shrub steppe, many studies have found that changes in shrub composition and density (e.g., shrub cover reduction or removal by chemical or fire treatments) have little effect on its abundance (Best 1972; Earnst et al. 2009). Our results at Browns Park suggest that sage sparrows and vesper sparrows were selecting not for or against mixed-shrub communities but more for their horizontal structural characteristics.

Vegetation structure greatly influenced Brewer's sparrow and lark sparrow, and both preferred open-canopy plant communities with tall, scattered shrubs. Throughout this study, we discovered structural characteristics that add to our understanding of species-specific songbird habitat. Brewer's sparrow and lark sparrow responded more strongly to horizontal and vertical characteristics of the plant communities than to species composition. Brewer's sparrow is considered a sagebrush obligate but occurs in mixed-shrub communities (Wiens and Rotenberry 1981; Medin 1990; Parrish et al. 2005). Earlier observations that Brewer's sparrows are negatively related to greasewood and spiny hopsage cover (Wiens and Rotenberry
1981; Walker 2004) are not supported by our study because densities were high in ecological sites dominated by greasewood and spiny hopsage. Its close association with basal gap, density of tall shrubs, and plant canopy height suggests it is selecting for these characteristics. Brewer's sparrows prefer landscapes with ample cover of tall shrubs $(50-150 \mathrm{~cm}$ tall) (Paige and Ritter 1999; Chalfoun and Martin 2007), an observation consistent with our results. However, we observed low densities in plant communities with desirable tall shrubs with undesirable horizontal characteristics (i.e., dense, closedcanopy shrub communities). Lark sparrow habitat studies, though limited, consistently report their dependence on both horizontal and vertical characteristics of shrub communities. Lark sparrow's preference for open grasslands with scattered, tall shrubs (Paige and Ritter 1999; Martin and Parrish 2000; Righter et al. 2004; Beason et al. 2005) parallels our findings. Lark sparrows will abandon sites with complete shrub removal (Bock and Bock 1987) and sites with high shrub density (Parrish et al. 2005). In a mixed-grass prairie, the majority of lark sparrow nests were associated with widely spaced broom snakeweed on grazed pastures (Lusk et al. 2003). In this study, lark sparrows favored broom snakeweed cover but only in short $(<100 \mathrm{~cm})$, open-canopy plant communities. Very few lark sparrows were documented in Saline Lowland sites, as they support tall, dense shrub communities.

Songbird diversity was closely associated with the structure of shrub communities rather than to specific shrub species-a common finding in shrub-steppe songbird research (Walcheck 1970; Best 1972; Parrish et al. 2005). We noted greater songbird diversity in structurally diverse shrub communities than in uniform, monotypic shrub communities, consistent with the literature (Wiens and Rotenberry 1981). Shrub-steppe songbirds require structural elements of habitat, and where there is complete removal of shrubs (either live or dead), Brewer's sparrows, lark sparrows, and sage sparrows abandon the area (Walcheck 1970; Bock and Bock 1987; Martin and Parrish 2000). Songbird diversity has been linked to horizontal and vertical plant community characteristics (MacArthur and MacArthur 1961; Roth 1976), and our results extend this link to the context of ecological sites. Because state-and-transition models are not currently developed for the ecological sites at Browns Park, we could not test specific relationships between songbirds and state-and-transition models. We recognize that alternate states will alter site structural characteristics and wildlife habitat on any ecological site. Structural characteristics will likely shift dramatically in alternate states within an ecological site and, so too should songbird density and diversity. Once state-and-transition models are fully developed and tested, they will provide more information about the variety of potential habitat within a given ecological site. Managers can adjust songbird habitat by managing for specific states or a variety of states on ecological sites. For example, at Browns Park, management efforts to maintain or increase the extent of shrub community structural diversity should accommodate several songbird species.

Our study diverges from earlier shrub-steppe songbird research primarily because we quantified structural characteristics by combining basal and canopy gap with height measurements, allowing us to discern between associations of songbirds with plant species composition versus vegetation 
structure. The array of ecological sites at Browns Park offers a variety of shrub communities to the songbirds and perhaps a greater variety than has been previously reported in any single study (e.g., Rotenberry and Wiens 1980; Wiens et al. 1986; Vander Haegen et al. 2000). The vegetation structure we documented clearly discerned shrub-steppe songbird habitat. Visual obstruction and line-point intercept commonly used to record structure in other studies can fail to capture the horizontal and vertical arrangement of plants in a community or to identify structural differences among different plant communities (Toledo et al. 2010). Structure of shrub-steppe sites is at least as important as plant species composition to songbirds.

\section{IMPLICATIONS}

Ecological sites are widely used as land classification units for rangeland management and provide a foundation for monitoring and management of ecosystem services. Wildlife habitat is a critical component of rangeland management decisions. Our study is the first documentation of the utility of ecological sites in characterizing songbird habitat. Ecological sites, when well described, provide a valuable tool to wildlife management because ecological sites are components of a landscape that can be delineated and easily incorporated into spatial models of resource use and availability. The patterns of association between songbirds and structural site characteristics suggest that the songbirds may be more responsive to shrub community structure than to specific shrub species. By incorporating key, distinguishing characteristics (e.g., basal and canopy gap, height, plant cover, and shrub density by height) into the descriptions of ecological sites, managers are provided with the tools needed to evaluate current songbird habitat and site conditions. In particular, we show that methods to monitor ecological sites can be effective tools to monitor both site characteristics and songbird habitat simultaneously. When combined, these methods describe the horizontal and vertical characteristics of plant communities that capture community characteristics of songbird habitat while recording characteristics used to evaluate ecological site function. Documenting these associations within the context of ecological sites facilitates this effort because the monitoring methods and units are commensurate with current practices and can be standardized for regional comparisons. It is critical that ecological site descriptions include habitat characteristics and monitoring methods that can differentiate among ecological sites and that simultaneously aid wildlife habitat management efforts. Even in areas lacking ecological site descriptions, the use of standardized methods to measure horizontal and vertical structure should capture songbird habitat characteristics.

\section{ACKNOWLEDGMENTS}

We thank W. King, R. Laubhan, and S. Beauchaine for support and several field technicians for data collection. Special thanks to Browns Park National Wildlife Refuge, NRCS (Colorado, Utah, and Wyoming Field Offices), BLM (Craig, Colorado Field Office), Colorado State Land Board (Moffat County), and Vermillion Livestock Company. We especially thank anonymous reviewers who provided insightful comments and greatly improved the quality of this manuscript.

\section{LITERATURE CITED}

Beason, J. R., R. Levad, and T. Leukering. 2005. Monitoring Colorado's birds: the 2004 field season report. Brighton, CO, USA: Rocky Mountain Bird Observatory. $66 \mathrm{p}$.

BEST, L. B. 1972. First-year effects of sagebrush control on two sparrows. Journal of Wildlife Management 36:534-544.

Bestelmeyer, B. T., J. R. Brown, K. M. Havstad, R. Alexander, G. Chavez, and J. E. HerRICK. 2003. Development and use of state and transition models for rangelands. Journal of Range Management 56:114-126.

Bibby, C. J., N. D. Burgess, D. A. Hill, and S. H. Mustoe. 2000. Bird census techniques. London, United Kingdom: Academic Press. 257 p.

Bock, C. E., AND J. H. Bock. 1987. Avian habitat occupancy following fire in a Montana shrubsteppe. Prairie Naturalist 19:153-158.

Boyle, S. A., And D. R. Reeder. 2005. Colorado sagebrush: a conservation assessment and strategy. Grand Junction, CO, USA: Colorado Division of Wildlife. 23 p.

Buckland, S. T., D. R. Anderson, K. P. Burnham, J. L. Laake, D. L. Borchers, and L. THOMAs. 2001. Introduction to distance sampling: estimating abundance of biological populations. New York, NY, USA: Oxford University Press. 432 p.

Buckland, S. T., R. E. Russell, B. G. Dickson, V. A. Saab, D. G. Gorman, and W. M. BLock. 2009. Analyzing designed experiments in distance sampling. Journal of Agricultural, Biological and Environmental Statistics 14:432-442.

Chalfoun, A. D., And T. E. Martin. 2007. Assessments of habitat preferences and quality depend on spatial scale and metrics of fitness. Journal of Applied Ecology 44:983-992.

Colorado Division of Wildlife. 2003. Conservation plan for grassland species in Colorado. Denver, CO, USA: Colorado Division of Wildlife. $205 \mathrm{p}$.

Dobler, F. C., J. Eby, C. Perry, S. Richardson, and M. Vander Haegen. 1996. Status of Washington's shrub-steppe ecosystem: extent, ownership, and wildlife/ vegetation relationships. Shrub-steppe research project. Olympia, WA, USA: Washington Department of Fish and Wildlife. $47 \mathrm{p}$.

Earnst, S. L., H. L. Newsome, W. L. Laframboise, and N. Laframboise. 2009. Avian response to wildfire in Interior Columbia Basin shrubsteppe. The Condor 111:370-376.

Herrick, J. E., J. W. Van Zee, K. M. Havstad, L. M. Burkett, and W. G. Whitford. 2005a. Monitoring manual for grassland, shrubland and savanna ecosystems. Volume 1: quickstart. Las Cruces, NM, USA: US Dept of Agriculture, Agricultural Research Service, Jornada Experimental Range. $36 \mathrm{p}$.

Herrick, J. E., J. W. Van Zee, K. M. Havstad, L. M. Burkett, and W. G. Whitford. 2005b. Monitoring manual for grassland, shrubland and savanna ecosystems. Volume 2: design, supplementary methods and interpretation. Las Cruces, NM, USA: US Dept of Agriculture, Agricultural Research Service, Jornada Experimental Range. 200 p.

HILL, M. O. 1973. Diversity and evenness: a unifying notation and its consequences. Ecology 54:427-432.

Knick, S. T., D. S. Dobkin, J. T. Rotenberry, M. A. Schroeder, W. M. Vander Haegen, And C. van Ripper III. 2003. Teetering on the edge or too late? Conservation research issues for avifauna of sagebrush habitats. The Condor 105:611-634.

KNICK, S. T., AND J. T. RotenBerRy. 1995. Landscape characteristics of fragmented shrubsteppe habitats and breeding songbird birds. Conservation Biology 9:1059-1071.

KreBs, C. J. 1999. Ecological methodology. 2nd ed. Menlo Park, CA, USA: Addison-Wesley Educational Publishers. 620 p.

Lusk, J. J., K. S. Wells, F. S. Guthery, and S. D. Fuhlendorf. 2003. Lark sparrow (Chondestes grammacus) nest-site selection and success in mixed-grass prairie. The Auk 120:120-129.

MacArthur, R. H., and J. W. MacArthur. 1961. On bird species diversity. Ecology 42:594-598.

Martin, J. W., And J. R. ParRish. 2000. Lark sparrow (Chondestes grammacus). In: A. Poole [ED.]. The birds of North America online. Ithaca, NY, USA: Cornell Lab of Ornithology, Available at: http://bna.birds.cornell.edu/bna/species/488. Accessed 5 March 2010.

Medin, D. E. 1990. Birds of a shadscale (Atriplex confertifolia) habitat in eastcentral Nevada. Great Basin Naturalist 50:295-298. 
National Research Council. 1994. Rangeland health: new methods to classify, inventory, and monitor rangelands. Washington, DC, USA: National Academies Press. 180 p.

Paige, C., And S. A. RitTer. 1999. Birds in a sagebrush sea: managing sagebrush habitats for bird communities. Boise, ID, USA: Partners in Flight Western Working Group. 49 p.

Parrish, J. R., D. A. Roberts, and F. P. Howe. 2005. Occurrence and density of breeding passerine birds in shrubland habitat in Utah. Albany, CA, USA: US Dept of Agriculture, Forest Service, General Technical Report PSW-GTR 191: p. 607-609.

Peacock, G., and D. Caudle. 2005. Interagency ecological site description manual: interagency memorandum of understanding. Fort Worth, TX, USA: US Dept of Agriculture, Natural Resources Conservation Service, Central National Technology Support Center, Available at: http://usda-ars.nmsu.edu/esd/ talks05/caudlepeacock2.pdf. Accessed 15 January 2010.

Pellant, M., P. Shaver, D. A. Pyke, and J. E. Herrick. 2005. Interpreting indicators of rangeland health version 4. Denver, CO, USA: US Dept of the Interior, Bureau of Land Management, National Science and Technology Center, Technical Reference 1734-6. 122 p.

RıcH, T. D. 1978. Cowbird parasitism of sage and Brewer's sparrows. The Condor 80:348.

Righter, R., R. Levad, C. Dexter, and K. Potter. 2004. Birds of western Colorado plateau and mesa country. Grand Junction, CO, USA: Grand Valley Audubon Society. $214 \mathrm{p}$.

RotenBerRY, J. T., AND J. A. Wiens. 1980. Habitat structure, patchiness, and avian communities in North American steppe vegetation: a multivariate analysis. Ecology 61:1228-1250.

Rотн, R. R. 1976. Spatial heterogeneity and bird species diversity. Ecology $57: 773-782$.
Soll Survey Staff, Natural Resources Conservation Service. 2006. Soil Survey Geographic (SSURG0) database for Moffat County, CO. Available at: http:// soildatamart.nrcs.usda.gov. Accessed 15 January 2006.

Stubbendieck, J., and S. L. Hatch. 1997. North American Range Plants. 5th ed. Lincoln, NE, USA: University of Nebraska Press. $501 \mathrm{p}$.

Thomas, L., J. L. Laake, J. F. Derry, S. T. Buckland, D. L. Borchers, D. R. Anderson, K. P. Burnham, S. Strindberg, S. L. Hedley, M. L. Burt, F. F. C. Marques, J. H. Pollard, and R. M. Fewster. 2005. User's guide Distance 5.0 release 2. St. Andrews, United Kingdom: Research Unit for Wildlife Population Assessment, University of St. Andrews. $324 \mathrm{p}$.

Toledo, D. P., J. E. Herrick, and L. B. AвBott. 2010. A comparison of cover pole with standard vegetation monitoring methods. Journal of Wildlife Management 74:600-604.

us Department of Agriculture, Natural Resources Conservation Service. 2010. The PLANTS database. Baton Rouge, LA, USA: National Plant Data Center, Available at: http://plants.usda.gov. Accessed 8 April 2010.

Vander Haegen, W., F. C. Dobler, and D. J. Pierce. 2000. Shrubsteppe bird response to habitat and landscape variables in Eastern Washington, USA. Conservation Biology 14:1145-1160.

Walcheck, K. C. 1970. Nesting bird ecology of four plant communities in the Missouri River Breaks, Montana. The Wilson Bulletin 82:370-382.

WALKER, B. 2004. Effects of management practices on grassland birds: Brewer's sparrow. Jamestown, ND, USA: Northern Prairie Wildlife Research Center Online, Northern Prairie Wildlife Research Center, Available at: http://www.npwrc.usgs. gov/resource/literatr/grasbird/brsp/brsp.htm. Accessed 11 February 2009.

Wiens, J. A., AND J. T. RotenBerRy. 1981. Habitat associations and community structure of birds in shrubsteppe environments. Ecological Monographs 51:21-41.

Wiens, J. A., J. T. RotenberRy, and B. Van Horne. 1986. A lesson in the limitations of field experiments: shrubsteppe birds and habitat alteration. Ecology 67:365-376. 